\title{
MEMBANGUN SIKAP TOLERANSI BERAGAMA DALAM MASYARAKAT PLURAL
}

\author{
Casram \\ Dosen Fakultas Ushuluddin UIN Sunan Gunung Djati Bandung \\ Jl. A.H. Nasution 105 Cibiru, Bandung 40614, Indonesia. \\ E-mail: dadahrobbani9@gmail.com
}

\begin{abstract}
The reality of social life is possible because of accommodating differences and diversities among human being. One of these diversities related to the choice of the faith, and therefore, we should be able to getting along either with the members of the same religious community as well as with those of others. In this case, religious tolerance is a necessity to guarantee social stability against the unwanted ideological force and even physical collisions in the society. Social and religious lives are not to be isolated from each other, but must be integrated into one another. Building educated and open minded religious community is a requirement to achieve this goal. The ideal religious tolerance should be built trough active participation from all members of diverse religious communities to achieve the same goals based on togetherness, inclusive attitude, respect and mutual understanding related to performing certain rituals and doctrins of each religions. The variety of typologies of interfaith relations, such as exclusivism, inclusivisme, pluralism, ect., are commonly formulated to bring these diversities into further step of harmonious religious dialogues. This article reminds us that our comprehension and implementation of religious doctrines should not stop in the claim of exclucivism ("I") which culminate in realizing personal relationship with God (solitary), nor in the claim of inclusivism ("You") with its concern with recruiting theological and ideological allies (solidarity), but also in the openness ("We") where our religious comprehension of human values get emphasized (humanistfunctional). In addition, all parties should suspend such a judgment as theological or ideological one directed to other religious community. This is a kind of phenomenological epoché we need to take if we wish to put religious tolerance into practice and not let it stay only on discourse level.
\end{abstract}

Keywords:

Religious tolerance; educated people; harmonious dialogue; epoché.

\begin{abstract}
Abstrak
Realitas kehidupan sosial menjadi mungkin karena ia mengakomodasi perbedaan dan keragaman di antara manusia. Salah satu dari keragaman ini berkaitan dengan pilihan keyakinan agama, dan karenanya kita hendaknya mampu bergaul apakah dengan anggota komunitas seagama dan juga dengan anggota komunitas agama lainnya. Dalam hal ini, toleransi agama merupakan sebuah keniscayaan untuk menjamin stabilitas sosial dari paksaan ideologis atau bahkan bentrokan fisik dalam masyarakat. Kehidupan sosial dan agama hendaknya tidak tersisih dari satu sama lain, dan musti terintegrasi kedalam satu sama lain. Membangun masyarakat terdidik dan umat beragama yang berpikiran terbuka merupakan prasyarat untuk mencapai tujuan ini. Toleransi agama yang ideal mustinya dibangun melalui partisipasi aktif semua anggota masyakarat beragama yang beragam guna mencapai tujuan-tujuan yang sama atas dasar kebersamaan, sikap inklusif, rasa hormat dan saling-paham terkait pelaksanaan ritual dan doktrin-dokrtin tertentu dari masing-masing agama. Beragam rumusan tentang tipologi hubungan antar agama, seperti eksklusifisme, inklusifisme, pluralisme, dst., lazim dikemukakan untuk membawa keragaman ini ke tahap dialog harmonis agama yang lebih jauh. Tulisan ini mengingatkan agar penghayatan dan praktik keagamaan tidak berhenti pada tahap klaim eksklusifisme ("Aku") yang berujung pada hubungan personal dengan Tuhan (soliter), tidak juga pada tahap inklusifisme ("Kamu") dengan perhatiannya pada perekrutan dukungan teologis atau ideologis (solidaritas), melainkan juga tahap keterbukaan ("Kita") dimana penghayatan religius atas nilai-nilai kemanusiaan mendapat penekanan (humanis). Semua pihak hendaknya menangguhkan penilaian yang semacam teologis dan ideologis terhadap ajaran dan praktik ritual penganut agama lain. Ini merupakan sejenis epoché fenomenologis yang perlu diambil jika kita hendak mewujudkan toleransi agama dan tidak membiarkannya hanya pada level wacana.
\end{abstract}

Kata kunci:

Toleransi beragama; masyarakat terdidik; dialog harmoni; epoché.

DOI: http://dx.doi.org/10.15575/jw.v1i2.588

Received: March 2016 ; Accepted: August 2016 ; Published: August 2016 


\section{A. PENDAHULUAN}

Toleransi berasal dari bahasa latin tolerantia, berarti kelonggaran, kelembutan hati, keringanan dan kesabaran. ${ }^{1}$ Secara umum istilah toleransi mengacu pada sikap terbuka, lapang dada, suka rela dan kelembutan. Unesco mengartikan toleransi sebagai sikap saling menghormati, saling menerima, saling menghargai di tengah keragaman budaya, kebebasan berekspresi dan karakter manusia. ${ }^{2}$ Toleransi harus didukung oleh cakrawala pengetahuan yang luas, bersikap terbuka, dialog, kebebasan berpikir dan beragama. Pendek kata toleransi setara dengan sikap positif, dan menghargai orang lain dalam rangka menggunakan kebebasan asasi sebagai manusia.

Toleransi beragama adalah toleransi yang mencakup masalah-masalah keyakinan dalam diri manusia yang berhubungan dengan akidah atau ketuhanan yang diyakininya. Seseorang harus diberikan kebebasan untuk meyakini dan memeluk agama (mempunyai akidah) yang dipilihnya masing-masing serta memberikan penghormatan atas pelaksanaan ajaran-ajaran yang dianut atau diyakininya. ${ }^{3}$

Toleransi beragama merupakan realisasi dari ekspresi pengalaman keagamaan dalam bentuk komunitas. ${ }^{4}$ Ekspresi pengalaman keagamaan dalam bentuk kelompok ini, menurut Joachim Wach, merupakan tanggapan manusia beragama terhadap realitas mutlak yang diwujudkan dalam bentuk jalinan sosial antar umat seagama ataupun berbeda agama, guna membuktikan bahwa bagi mereka realitas mutlak merupakan elan vital keberagamaan manusia dalam pergaulan sosial, dan ini terdapat dalam setiap agama, baik yang masih hidup bahkan yang sudah punah.

${ }^{1}$ Hornby AS, Oxford Advanced Learner'sDictionary (Oxford: University Printing House, 1995), 67.

${ }^{2}$ Michael Walzer, On Toleration Castle Lectures in Ethics, Politics, and Economics (New York: Yale University Press, 1997), 56.

${ }^{3}$ J. Cassanova, Public Religions In The Modern World (Chicago: Chicago University Press, 2008),. 87.

${ }^{4}$ Joachim Wach, The Comparative Study of Religion (New York: Colombia University Press, 1958), 121132.
Menurut Fritjhof Schuon, ${ }^{5}$ agama secara eksoteris $^{6}$ terlahir di dunia ini berbeda-beda. Akan tetapi terlepas dari perbedaan yang muncul dalam agama-agama, secara esoterik ${ }^{7}$ agama-agama yang ada di dunia memiliki prinsip yang sama, yaitu bersumber dan tertuju pada Supreme Being. Cara Schuon membedakan kedua aspek agama ini bisa diterapkan sebagai panduan bagaimana manusia yang berbeda agama bertemu satu sama lain dalam memberikan peran mereka sebagai hamba TuhanYang Esa di dunia ini.

Toleransi merupakan bentuk akomodasi dalam interaksi sosial. $^{8}$ Manusia beragama secara sosial tidak bisa menafikan bahwa mereka harus bergaul bukan hanya dengan kelompoknya sendiri, tetapi juga dengan kelompok berbeda agama. Umat beragama musti berupaya memunculkan toleransi untuk menjaga kestabilan sosial sehingga tidak terjadi benturan-benturan ideologi dan fisik di antara umat berbeda agama.

Artikel ini ditulis dengan tujuan agar kehidupan beragama dapat terbina harmonis. Kehidupan bergama dalam masyarakat plural akan terjalin harmonis bila semua umat yang

\footnotetext{
${ }^{5}$ Fritjhof Schuon adalah seorang filosof Perancis yang beraliran mistik. Dia menulis banyak tentang mistisisme agama-agama Barat dan Timur. Cukup banyak karyanya, di antaranya, Frithjof Schuon, The Transcendent Unity of Religions, cet. ke-2 (Wheaton: Quest Books Theosophical Publishing House, 2005); Fithjof Schoun, Islam and the Perennial Philosophy, terj. J.Peter Hobson (New York: World of Islam Festival Publishing Company, 1976), dan sebagainya.

${ }^{6}$ Eksoteris adalah konsep yang menyatakan bahwa agama-agama yang ada di dunia ini berbeda perwujudannya. Perbedaan ini disebabkan oleh perwujudan sejarah. Dengan adanya pemahaman eksoteris ini, agama-agama di dunia, terutama agamaagama yang masih hidup, tampil memiliki nama-nama yang berbeda, seperti Islam, Kristen Katolik, Yahudi, Konghucu, Budha, Hindu dan sebagainya.

${ }^{7}$ Esoteris adalah suatu pemahaman bahwa pada dasarnya agama-agama yang ada di dunia ini, baik yang sudah punah maupun yang masih terlihat sekarang, secara batin memiliki tujuan yang sama yaitu menuju pada satu Tuhan. Konsep ini digagas oleh Frithjof Schuon dalam karyanya Schuon, The Transcendent Unity of Religions.

${ }^{8}$ Graham C. Kinloch, Sociological Theory:Development and Major Paradigm (Bandung: Pustaka Setia, 2005), 35 .
} 
berbeda agama memiliki sikap toleransi terhadap satu sama lain. Sejarah mencatat banyak pertumpahan darah atas nama agama terjadi akibat tidak adanya kesaling-pahaman antara satu sama lain, yang semestinya terwujud dalam sikap toleransi.

Tulisan ini juga bermaksud untuk memperkaya khazanah intelektual khususnya kajian sosial berbasis fenemenologi agama yang menekankan bahwa kajian toleransi beragama tidak semata-mata dimunculkan sebagai isapan jempol, tetapi lebih dari itu menggugah perasaaan hati yang sebenarnya dari masingmasing umat bergama. Dalam tulisan ini ditampilkan bagaimana sikap epoché melandasi dan dijadikan ukuran untuk menciptakan sikap toleransi antar umat beragama yang proposional. Dengan dimilikinya sikap epoché, setiap umat beragama akan mudah bergaul dengan umat lain tanpa melepaskan keyakinan agama yang dianutnya, atau bahkan hingga tercipta pemahaman yang baik atas agama lain dengan tanpa merasa tersepelekan pemahamannya atas agama yang dipeluknya sendiri.

\section{B. HASIL DAN PEMBAHASAN \\ 1. Agama dalam Masyarakat Multi- kultural}

Menurut MacIver, masyarakat dibentuk oleh struktur yang tidak kelihatan dan merupakan kumpulan dari beragam hubungan manusia yang dibangun dan diubah oleh manusia itu sendiri. ${ }^{9}$ Masyarakat bergerak dinamis sesuai dengan perkembangan jaman.

Dalam masyarakat sederhana atau primitif, manusia memiliki karakteristik yang serba homogen baik dalam budaya, agama maupun struktur sosial. Agama yang dipahami oleh masyarakat seperti ini adalah agama yang dekat dengan simbol-simbol. Simbol-simbol ini memiliki peran dominan terhadap keberagamaan mereka. Kebanyakan dari masyarakat sederhana ini berpendidikan rendah atau dalam lingkup ordinary people. Mereka memahami agama orang lain dengan perasaan

${ }^{9}$ Dalam James. D. Proctor, Science, Religion and the Human Experience, (New York: Oxford University Press, 2005), 90. antipati. Toleransi yang dikembangkan dalam masyarakat ini tidak terjalin atau berjalan normal. Mereka mudah tersentuh atau tersinggung bila ajaran keyakinan agama mereka sepertinya dihina oleh pemeluk agama lain. Mereka merespon langsung dengan mempertahankan taruhan jiwa. Mereka memahami agama orang lain dengan sikap antipati.

Masyarakat kompleks atau masyarakat multikultural tersusun dari keanekaragaman budaya, masyarakat dan struktur sosial. Keanekaragaman adalah fakta yang tidak bisa dielakkan dalam kehidupan kolektif dan tidak bisa diharapkan eksistensinya atau tidak dapat ditekan tanpa tingkat kekerasan yang bisa diterima. Terlebih lagi sejak manusia terikat dan dibentuk oleh kebudayaan, penghormatan diri mereka secara erat terikat dengan penghormatan pada kebudayaannya. Penghormatan pada kebudayaan ini menumbuhkan rasa kesetiaan, memberi rasa percaya diri dan keberanian untuk berinteraksi dengan kebudayaan lain.

Karakter interaksi antar kebudayaan dalam masyarakat multikultural adalah terjadinya asimilasi kebudayaan. Begitu juga dalam hal keberagamaan. Orang-orang yang hidup dalam masyarakat multikultural berasimilasi mengenai bagaimana keberagamaan yang baik dalam masyarakat dengan komposisi kepemelukan agama yang heterogen. Hal ini menciptakan rasa toleransi dan kerjasama antar budaya-agama. Proses asimilasi ini muncul bukan hanya untuk kelompok minoritas tetapi juga untuk kelompok mayoritas. Mereka beranggapan bahwa masyarakat memiliki struktur moral dan kebudayaan yang padu dan koheren. Hal seperti ini jarang menjadi permasalahan. Meskipun struktur moral dan kebudayaan masyarakat memiliki koherensi internal, struktur itu tidak sepenuhnya sama dan padu. Struktur tersebut berbeda-beda menurut kelas, agama, wilayah dan disusun dari bermacam-macam rangkaian pemikiran bahkan yang bertentangan serta terdiri dari nilai-nilai dan praktek-praktek yang dapat ditafsirkan dan dihubungkan dengan beberapa cara yang berbeda. Golongan assimilasionis mengabaikan semua ini dan menawarkan satu 
pandangan yang sangat sempit dan menyimpang tentang kebudayaan nasional atau menyamakan struktur kelompok minoritas dengan kelompok yang lebih dominan. ${ }^{10}$

Dalam masyarakat multikultural, pengikut atau pemeluk agama memainkan peranan dominan bagi ajaran agama yang dipeluknya atau bahkan di antara mereka ada sekelompok orang yang acuh terhadap agama yang mereka peluk. Kenyaataan seperti ini akan mengganggu dan juga sekaligus membantu memahami keberadaan suatu agama dengan umatnya.

Ada dua kelompok masyarakat beragama dalam masyarakat multikultural, yaitu masyarakat beragama educated people dan masyarakat beragama ordiniary people. Kedua masyarakat beragama ini berbeda dalam memperlakukan agama yang mereka peluk. Bagi masyarakat beragama educated people, memahami ajaran agama harus mengikutsertakan analisis rasional dan mengesampingkan pemahaman intuitif dan simbolik. Mereka mudah diajak bertoleransi terhadap agama dan pemeluk agama lain. Sebaliknya, masyarakat beragama ordiniary people memahami ajaran agama penuh dengan simbolsimbol dan tidak mempergunakan analisis rasional. Mereka mudah tersulut emosi dan sangat susah bertoleransi dengan agama dan pemeluk agama lain. Kelompok ini mudah digerakkan oleh sekelompok orang atau komunitas baik yang beraliansi pada politik maupun pada sosial budaya.

\section{Toleransi Beragama dalam Masyarakat Multikultural}

Dalam masyarakat multikultural yang identik dengan masyarakat serba majemuk baik dalam politik, budaya atau bahkan agama, manusia beragama cenderung mengalami konflik akibat adanya berbagi kepentingan yang dihadapinya. Kelompok bergama yang secara ekonomi kuat akan mampu mengalahkan kelompok agama yang lemah secara ekonomi. Pada sisi lain kelompok yang

\footnotetext{
${ }^{10}$ Bikhu Parekh, Rethinking Multiculturalism; Cultural Diversity andPolitical Theory (New York: Palgrave Macmillan, 2005), 78.
}

dianggap lemah dalam bidang perekonomian merasa tersisih dan terpinggirkan akibat tidak bisa bersaing dengan kelompok bergama yang kuat dari sisi ekonomi. Kelompok ini dalam menjalankan ekonominya berupaya mengimbangi kelompok kuat, serta memasukkan nilainilai supranatural. Dengan begitu, mereka merasa kuat secara kualitas spiritual sekalipun dalam skala kuantitas ekonomi kecil. ${ }^{11}$

Kenyataan seperti di atas adalah respon yang mendasar dari kelompok kecil. Respon ini bisa muncul dalam bentuk kelompok fundamentalis. Kelompok ini bereaksi untuk menjawab kelompok yang kuat dalam sistem perekonomian dengan menggulirkan berbagai konsep konservatif, ortodoks atau tradisional menuju konsep-konsep fundamentalis modern. Mereka masuk dalam area masyarakat sipil, dunia permodalan dan universitasuniversitas. $^{12}$

Sekalipun kelompok fundamentalis modern seperti ini secara ekonomi lemah, namun ia memiliki berbagai strategi kuat dalam media informasi yang menginspirasi berbagai kecenderungan militansi keagamaannya. Mereka menguasai berbagai jaringan telekomunikasi canggih dan mampu menyebarkan gagasan ideologisnya untuk menghancurkan kekuatan jumlah besar. Mereka bekerja untuk agama dan kepentingan politik keagamannya. ${ }^{13}$

Dalam masyarakat multikultural, pengikut atau pemeluk agama memainkan peranan dominan bagi ajaran agama yang dipeluknya atau bahkan di antara mereka ada sekelompok orang yang acuh terhadap agama yang mereka peluk. Kenyaataan seperti ini akan mengganggu dan juga sekaligus membantu memahami keberadaan suatu agama dengan umatnya.

Dalam keragaman agama-agama, yang muncul dalam suatu masyarakat multikultural baik yang memiliki sistem pemerintahan republik atau monarki, perbedaan sering menjadi pemicu munculnya berbagai ham-

\footnotetext{
${ }^{11}$ Marty, When Faith Collide, 48.

${ }^{12}$ Kinloch, Sociological theory:Development and Major Paradigm, 67.

${ }^{13}$ Kinloch, Sociological theory:Development and Major Paradigm, 89.
} 
batan dalam kohesi sosial. ${ }^{14}$ Perbedaan agama tersebut telah meletakkan pemahaman keagamaan dalam kerangka dua kubu umat beragama: satu, kubu umat beragama tuan rumah; kedua, kubu umat beragama pendatang. Kubu umat beragama tuan rumah biasanya memiliki kuantiatas umat yang mayoritas, sedangkan kubu umat beragama pendatang biasanya menduduki posisi minoritas. Kedua kubu ini saling bertubrukan dalam pergaulan sosial, bila di antara mereka menjadikan perbedaan agama sebagai hambatan dalam mengintegrasikan nilai-nilai suatu bangsa atau masyarakat.

Munculnya kesadaran antar umat beragama yang diwujudkan dalam toleransi bisa menekan atau meminimalisasi bentrokan di antara mereka. Moto agree in disagrement ${ }^{15}$ menjadi modal sosial yang kuat dalam toleransi beragama. Toleransi beragama yang dikembangkan bukan hanya menghargai teologi dan iman masing-masing agama dan umat beragama, tetapi juga memahami dan menghargai budaya dari umat beragama tersebut. Toleransi beragama mampu memberikan dukungan bagi terbentuknya masyarakat madani yang diinspirasi oleh nilai-nilai supranatural.

Ada dua tipe toleransi beragama: pertama, toleransi beragama pasif, yakni sikap menerima perbedaaan sebagai sesuatu yang bersifat faktual. Kedua, toleransi beragama aktif, yakni toleransi yang melibatkan diri dengan yang lain di tengah perbedaan dan keragaman. Toleransi aktif merupakan ajaran semua agama. Hakekat toleransi adalah hidup berdampingan secara damai dan saling menghargai di antara keragaman. Praktek toleransi di sebuah negara sering mengalami pasang surut. Pasang surut ini dipicu oleh pemaknaan distingtif yang bertumpu pada relasi "mereka" dan "kita".

\footnotetext{
${ }^{14}$ Parekh, Rethinking Multiculturalism; Cultural Diversity andPolitical Theory, 99.

${ }^{15}$ Moto agree in disagreement adalah moto yang diungkapkan oleh Mukti Ali untuk menciptakan rasa epoché dan toleransi antar umat beragama. Moto itu menyatakan toleransi beragama bukan hanya terjadi dalam kelompok beragama yang sama, tetapi juga dengan kelompok beragama yang berbeda.
}

Toleransi beragama yang dilakukan dengan penuh kesadaran akan melahirkan sikap inklusif umat bergama. Sikap ini menganggap agama sendiri benar tetapi masih memberikan ruang untuk menyatakan kebenaran agama lain yang diyakini benar oleh umatnya. Sikap inklusif umat beragama akan mampu meruntuhkan sikap ekstrimis dan eksklusif umat beragama, yang biasanya melahirkan pemahaman fanatik buta dan radikalisme bahkan terorisme yang abadi terhadap umat berbeda agama.

Toleransi itu cukup mensyaratkan adanya sikap membiarkan dan tidak menyakiti orang atau kelompok lain, baik yang berbeda maupun yang sama. Toleransi ditumbuhkan oleh kesadaran yang bebas dari segala macam bentuk tekanan atau pengaruh serta terhindar dari hipokrisis. Toleransi mengandung maksud untuk memungkinkan terbentuknya sistem yang menjamin keamanan pribadi, harta benda dan unsur-unsur minoritas yang terdapat dalam masyarakat. Ini direalisasikan dengan menghormati agama, moralitas dan lembagalembaga mereka serta menghargai pendapat orang lain dan perbedaan-perbedaan yang ada di lingkungannya tanpa harus berselisih dengan sesamanya hanya karena berbeda keyakinan atau agama. Dalam kaitan dengan agama, toleransi mencakup masalah-masalah keyakinan pada diri manusia yang berhubungan dengan akidah atau yang berhubungan dengan ketuhanan yang diyakininya. Seseorang harus diberikan kebebasan untuk meyakini dan memeluk agama (mempunyai akidah) masing-masing yang dipilihnya serta memberikan penghormatan atas pelaksanaan ajaran-ajaran yang dianut atau diyakininya.

\section{Tipologi Sikap Keberagamaan}

Komarudin Hidayat menyebutkan ada lima tipologi sikap keberagamaan, yakni "eksklusivisme, inklusivisme, pluralisme, eklektivisme, dan universalisme". Masing-masing dari kelima tipologi ini tidak berarti saling terlepas dan terputus satu sama lainnya dan tidak pula permanen, tetapi lebih tepat dikatakan sebagai sebuah kecenderungan menonjol, mengingat setiap agama maupun 
sikap keberagamaan senantiasa memiliki potensi untuk melahirkan kelima sikap di atas. $^{16}$

Sekalipun terdapat perbedaan tipe-tipe teologis keberagamaan di antara para pengaji agama-agama - Panikkar, misalnya, menyebut tiga tipologi: eksklusif, inklusif, dan paralelisme - tetapi secara esensial penyebutan tipologi-tipologi itu mengandung makna dan pengertian yang sama. Oleh karena itu, kita akan membahas tipologi-tipologi beragama itu.

\section{a. Eksklusivisme}

Sikap eksklusivisme melahirkan pandangan bahwa ajaran yang paling benar hanyalah ajaran agama sendiri, sedangkan agama lain sesat dan wajib dikikis, atau pemeluknya dikonversi, sebab agama dan penganutnya terkutuk dalam pandangan Tuhan. ${ }^{17}$ Sikap ini merupakan pandangan yang dominan dari zaman ke zaman, dan terus dianut hingga dewasa ini. ${ }^{18}$ Tuntutan kebenaran yang dipeluknya mempunyai ikatan langsung dengan tuntutan eksklusivitas. Artinya, kalau suatu pernyataan dinyatakan, maka pernyataan lain yang berlawanan tidak bisa benar.

Menurut Nurcholish Madjid, ${ }^{19}$ bagi sikap keberagamaan eksklusif ini, agama-agama lain adalah jalan yang salah, yang menyesatkan bagi para pemeluknya. Paradigma ini merupakan pandangan yang dominan dari zaman ke zaman dan terus dianut hingga dewasa ini: "Agama sendirilah yang paling benar, yang lain salah".

Bagi agama Kristen, inti pandangan eksklusivisme adalah bahwa Yesus adalah satusatunya jalan yang syah untuk keselamatan. "Akulah jalan dan kebenaran dan hidup. Tidak ada seorangpun yang datang kepada Bapa, kalau tidak melalui Aku" (Yohanes 14:6). Juga, dalam ayat lain (Kisah Para Rasul 4,12) disebutkan:

\footnotetext{
${ }^{16}$ Komaruddin Hidayat, Menafsirkan Kehendak Tuhan (Bandung: Mizan, 2003), 45.

${ }^{17}$ Hidayat, Menafsirkan Kehendak Tuhan, 89.

${ }^{18}$ Hidayat, Menafsirkan Kehendak Tuhan, 90.

19 Nurcholis Madjid dalam Hidayat, Menafsirkan Kehendak Tuhan, 46.
}

Dan keselamatan tidak ada di dalam siapapun juga selain di dalam Dia, sebab di bawah kolong langit ini tidak ada nama lain yang diberikan kepada manusia yang olehnya kita dapat diselamatkan. ${ }^{20}$

Menurut Budhy Munawar Rachman, ${ }^{21}$ dalam kasus Islam, sekalipun tidak ada semacam kuasa gereja dalam agama Kristen, khususnya Katolik yang bisa memberi fatwa menyeluruh seperti contoh di atas, banyak penafsir sepanjang masa yang menyempitkan Islam pada pandangan-pandangan eksklusif. Beberapa ayat yang biasa dipakai sebagai ungkapan eksklusifitas Islam itu antara lain :

Hari ini orang kafir sudah putus asa untuk mengalahkan agamamu. Janganlah kamu takut kepada mereka; takutlah kepada-Ku. Hari ini Ku-sempurnakan agamamu bagimu dan $\mathrm{Ku}$-cukupkan karunia-Ku untukmu dan Ku-pilihkan Islam menjadi agamamu (QS Al-ma>'idah [5]:3).

Kemudian ayat yang berbunyi "Barangsiapa menerima agama selain Islam (tunduk kepada Allah) maka tidaklah akan diterima dan pada hari akhirat ia termasuk golongan yang rugi", (QS Al-'imra>n [3]:85).

Namun begitu, kata Komarudin Hidayat, sikap eksklusif, yakni merasa agama sendiri paling baik dan benar, sementara yang lain tidak masuk hitungan, tidaklah selamanya salah dalam beragama. Dalam pengertiannya sebagai sikap agnostik, tidak toleran, dan mau menang sendiri, eksklusifisme tentu tidak dibenarkan oleh etika agama manapun di dunia. Tetapi, jika yang dimaksud dengan eksklusif adalah berkenaan dengan kualitas, mutu, atau keunggulan suatu produk atau ajaran agamadengan dukungan bukti-bukti dan argumen yang fair, maka setiap manusia sesungguhnya mencari agama yang eksklusif dalam arti excellent tersebut, sesuai dengan selera dan keyakinanya. ${ }^{22}$

20 Budi Munawar Rahman dalam Alwi Shihab, Islam Inklusif (Jakarta: Taraju Press, 2005), 57.

${ }^{21}$ Gerge A. Lindbeck, The Natural Of Doctrne: Religion and Theology in a Post Liberal Age (Philadelphia: The Westminster Press, 1985), 56.

${ }^{22}$ Lindbeck, The Natural Of Doctrne: Religion and Theology in a Post Liberal Age, 90. 
Hanya saja, dalam jargon hidup politik modern, bersikap hidup eksklusif mengandung makna suatu sikap hidup yang mengabaikan sikap hidup pluralistik, yakni sikap hidup yang benar, dan oleh sebab itu merupakan sikap hidup manusia yang beriman. ${ }^{23}$ Sikap ini dapat menimbulkan kesukaran-kesukaran. Pertama, ia membawa bahaya yang nyata akan intoleransi, kesombongan, dan penghinaan terhadap yang lain. Kedua, sikap ini pun mengandung kelemahan intrinsik karena mengandaikan konsepsi kebenaran yang seolah logis secara murni dan sikap yang tidak kritis terhadap kenaifan epistimologis. ${ }^{24}$

Friedrich Heiler, seorang ahli Ilmu Perbandingan Agama dari Marburg, menyatakan bahwa secara tradisional tradisi agama Barat adalah eksklusif dalam sikap mereka terhadap agama-agama lain dengan memberikan kepada agama mereka sendiri validitas mutlak. ${ }^{25}$

Terlepas dari adanya kelemahan dalam sikap eksklusif penganut suatu agama, komitmen dan sikap tegas dalam memelihara dan mempertahankan kebenaran agamanya biasanya dapat dipandang positif. Sebab, sikap eksklusif tidak selamanya bisa disalahkan atau dipandang negatif; sikap eksklusif seseorang lebih banyak disebabkan oleh faktor kurangnya pengetahuan dan pemahaman tentang agamanya, atau bahkan oleh pengaruh lingkungan sosial dan kultural tempat ia hidup, yang turut membentuk cara ia menjalankan agamanya.

\section{b. Inklusivisme}

Inklusivisme merujuk pada sikap dan pandangan keberagamaan seseorang bahwa di luar agama yang dipeluknya juga terdapat kebenaran, meskipun tidak seutuh atau sesempurna agama anutannya. Di sini masih didapatkan toleransi teologis dan iman. Menurut Nurcholish Madjid, sikap inklusif meman-

\footnotetext{
${ }^{23}$ Reinhold Niebuhr, The Tolerance and Intolerance In Early Judiasm and Christianity (Cambridge: Cambridge Universdity Press, 1998), 76.

${ }^{24}$ Paul Elmen, The Restoration of Meaning to Contemporary Life (New York: Garden City, 2012), 56.

${ }^{25}$ Mircea Eliade, The Sacred and The Profan (New York, 1959), 76.
}

dang agama-agama lain sebagai bentuk implisit dari agama kita. ${ }^{26}$

Paradigma keberagamaan inklusif membedakan antara salvific presence (kehadiran yang membawa kepada keselamatan) dan aktifitas Tuhan yang terdapat dalam tradisitradisi agama lain, dimana penyelamatan dan aktifitas Tuhan sepenuhnya dalam Yesus Kristus. Menjadi "inklusif" berarti percaya bahwa seluruh kebenaran agama non-Kristiani mengacu kepada Kristus. Paradigma ini, membaca agama orang lain dengan kacamata sendiri. Sikap beragama inklusif ini juga bisa berarti memasukkan orang lain dalam kelompok kita. $^{27}$

Pandangan yang paling ekspresif dari paradigma inklusif ini tampak pada dokumen Konsili Vatikan II, yang mempengaruhi seluruh komunitas Katolik sejak 1965. Dokumen yang berkaitan dengan pernyataan inklusif dalam kaitan dengan agama lain, ada pada "Deklarasi tentang Hubungan Gereja dan Agama-agama Non-Kristiani”.

Teolog terkemuka yang menganut aliran ini adalah Karl Rehner, yang pandanganpandangannya termuat dalam karya terbesarnya the Theological Investigation yang berjilid 20, dalam "Christianity and the Non-Christian Religions", jilid 5. Persoalan yang diketengahkannya adalah bagaimana terhadap orang-orang yang hidup sebelum karya penyelamatan itu hadir, atau orang-orang sesudahnya tetapi tidak pernah tersentuh oleh Injil? Di sini, Rahner memunculkan istilah inklusif, the Anonymous Christian (Kristen anonim), yaitu orang-orang non-Kristen. Menurut pandangannya, Kristen anonim juga akan selamat, sejauh mereka hidup dalam ketulusan hati terhadap Tuhan, karena karya Tuhan pun ada pada mereka, walaupun mereka belum pernah mendengar Kabar Baik. ${ }^{28}$

Dalam contoh Islam, juga sering dikemukakan misalnya istilah dari seorang filsuf Muslim abad XIV, Ibn Taymiyah, yang membedakan antara orang-orang dan agama Islam umum (non-Muslim par exellance),

\footnotetext{
${ }^{26}$ Eliade, The Sacred and The Profan, 89.

${ }^{27}$ Eliade, The Sacred and The Profan, 80.

${ }^{28}$ Eliade, The Sacred and The Profan, 89.
} 
serta orang-orang dan agama Islam khusus (Muslim par exellence). Kata Islam sendiri di sini diartikan sebagai "sikap pasrah kepada Tuhan". Mengutip Ibn Taymiyah, "semua nabi dan pengikut mereka seluruhnya disebut oleh Allah adalah orang-orang Muslim".

Hal itu sebagaimana dalam Alquran (Ali 'Imra>n [3]:85), "Barangsiapa yang menganut suatu din selain al-Islam maka tidak akan diterima daripadanya al-din dan di akhirat ia termasuk yang merugi". Dan firman-Nya, "sesungguhnya al-din di sisi Allah ialah al-Islam" (Ali 'Imra>n [3]:19). Menurut tafsir penganut "Islam Inklusif", sekalipun para nabi mengajarkan pandangan hidup yang disebut al-Islam, halitu tidak berarti bahwa mereka dan kaumnya menyebut secara harfiah agama mereka al-Islam dan mereka sendiri sebagai orang-orang Muslim. Itu semua hanyalah peristilahan bahasaArab. Para nabi dan rasul, dalam dakwah mereka pada dasarnya menggunakan bahasa kaumnya masing-masing. Alquran (Ibra $>$ hi \}m [14]:4) menegaskan, bahwa "Kami tidak mengutus seorang Rasul kecuali dengan bahasa kaumnya." 29 Dengan demikian, kalangan Islam inklusif menganut suatu pandangan bahwa agama semua nabi adalah satu.

Sikap inklusif cenderung menginterpretasikan kembali pelbagai hal dengan cara sedemikian rupa, sehingga hal-hal tersebut tidak saja cocok tetapi juga dapat diterima. Sikap demikian akan membawa ke arah universalisme ciri eksistensial atau formal ketimbang isi esensialnya. Suatu kebenaran doktrinal hampir tidak dapat diterima sebagai universal jika ia terlalu bersikeras mempertahankan isinya yang spesifik, karena pencerapan isi selalu mengandaikan perlunya suatu 'forma mentis' yang khusus. Sikap menerima yang toleran akan adanya tataran-tataran yang berbeda, sebaliknya, akan lebih mudah dicapai. Sementara, suatu pola payung atau struktur formal dapat dengan mudah

${ }^{29}$ Gavin Flood, Beyond Phenomenology: Rethinking The Study of Religion (London: Bloomsbury Academic, 2013), 45. merangkul sistem-sistem pemikiran yang berbeda. ${ }^{30}$

Sikap inklusivitas memuat kualitas keluhuran budi dan kemuliaan tertentu. Anda dapat mengikuti jalan anda sendiri tanpa perlu mengutuk yang lain. Ibadah anda dapat menjadi konkrit dan pandangan anda dapat menjadi universal. Tetapi, pada sisi lain, sikap inklusivitas pun membawa beberapa kesulitan:

Pertama, ia juga menimbulkan bahaya kesombongan, karena hanya andalah yang mempunyai privilege (hak istimewa) atas penglihatan yang meliputi semua dan sikap toleran; andalah yang menentukan bagi yang lain tempat yang harus mereka ambil dalam alam semesta.

Kedua, jika sikap ini menerima ekspresi 'kebenaran agama' yang beraneka ragam sehingga dapat merengkuh sistem-sistem pemikiran yang paling berlawanan sekalipun, maka ia terpaksa menjadikan kebenaran bersifat relatif murni. Kebenaran dalam arti ini tidak mungkin mempunyai isi intelektual yang independen, karena berbeda atau berlainan dengan orang lain. ${ }^{31}$

\section{c. Pluralisme atau Paralelisme}

Panikkar dan Budhy Munawar Rachman masing-masing menyebutkan istilah pluralisme dan paralelisme. Sikap teologis paralelisme bisa terekspresikan dalam macammacam rumusan, misalnya: "agama-agama lain adalah jalan yang sama-sama sah untuk mencapai Kebenaran yang Sama"; "agamaagama lain berbicara secara berbeda, tetapi merupakan Kebenaran-kebenaran yang sama sah"; atau "setiap agama mengekspresikan bagian penting sebuah kebenaran". ${ }^{32}$

Paradigma ini percaya bahwa setiap agama mempunyai jalan keselamatan sendiri. Karena itu, klaim kristiani bahwa ia adalah satu-satunya jalan (eksklusif), atau yang melengkapi atau mengisi jalan yang lain (inklusif), harus

\footnotetext{
${ }^{30}$ Flood, Beyond Phenomenology: Rethinking The Study of Religion, 78.

${ }^{31}$ Flood, Beyond Phenomenology: Rethinking The Study of Religion, 80.

${ }^{32}$ Flood, Beyond Phenomenology: Rethinking The Study of Religion, 87.
} 
ditolak demi alasan-alasan teologis dan fenomenologis. ${ }^{33}$

Menurut Komarudin Hidayat, sikap pluralisme lebih moderat dari sikap inklusivisme, atau bahkan dari eksklusivisme. Ia berpandangan bahwa secara teologis pluralitas agama dipandang sebagai suatu realitas niscaya yang masing-masing berdiri sejajar (paralel) sehingga semangat misionaris atas dakwah dianggap tidak relevan. ${ }^{34}$

\section{d. Eklektisisme}

Eklektisisme adalah suatu sikap keberagamaan yang berusaha memilih dan mempertemukan berbagai segi ajaran agama yang dipandang baik dan cocok untuk dirinya sehingga format akhir dari sebuah agama menjadi semacam mosaik yang bersifat eklektik. $^{35}$

Sikap keberagamaan seperti ini muncul akibat ketidakberdayaan ajaran satu agama dan melihat ada kekuatan ajaran agama lain. Kelompok ini muncul biasanya dari mereka yang kecewa dengan berbagai janji muluk para tokoh agama yang hanya mementingkan kebenaran ajarannya sendiri padahal pada di sisi lain agamanya tak mampu menyelesaikan berbagai persoalan hidup umatnya.

Pilihan praktik keagamaan seperti ini kelihatannya sempurna karena di dalamnya ajaran-ajaran dari berbagai agama dapat saling mengisi. Namun, sikap keberagamaan seperti ini mengandung ketegangan, yaitu apakah setiap umat beragama senang dengan sikap mencari keunggulan dari satu agama dengan agama lain dan dijadikan satu wadah. Hal ini tidaklah realistis bahkan akan menciptakan ketegangan antar umat beragama.

Kelompok manusia yang senang mencaricari ajaran dari berbagai agama untuk kemudian disatukan dalam satu wadah biasanya ditemukan dalam masyarakat global yang pada akhirnya mereka akan menciptakan sebuah agama baru yang berbeda dari agama yang dipeluk sebelumnya. Orang-orang yang

${ }^{33}$ Flood, Beyond Phenomenology: Rethinking The Study of Religion, 90.

${ }^{34}$ Dormort Moran, Introduction To Phenomenology (New York, The Westminster Press, 2012), 34.

${ }^{35}$ Moran, Introduction To Phenomenology, 17. memiliki sikap beragama seperti ini lemah terhadap ajaran agamanya sendiri dan menganggap agama sebagai tidak berbeda dari ilmu pengetahuan biasa.

\section{e. Universalisme}

Universalisme beranggapan bahwa pada dasarnya semua agama adalah satu dan sama. Hanya saja, karena faktor historis-antropologis, agama lalu tampil dalam format yang plural. $^{36}$

Menurut Raimundo Panikkar, jika suatu perjumpaan agama terjadi, baik dalam fakta yang nyata maupun dalam suatu dialog yang disadari, maka orang membutuhkan metafora dasar untuk mengutarakan masalah-masalah yang berbeda. Oleh karena itu, tiga macam model perjumpaan agama bisa berguna, yakni model fisika: pelangi; model geometeri: invarian topologis; dan model antropologis: bahasa. $^{37}$

Paradigma atau sikap beragama yang berkembang di dunia Kristen tersebut, ada hubungannya dengan teori W.C. Smith dalam mengaji agama orang lain. Ada beberapa tahapan dalam hubungan antar agama yang akhirnya memunculkan dialog harmonis antar umat beragama. Tahapan-tahapan ini dianalogkan dalam bentuk: I, You dan We. "I" menunjukkan eksklusif. "You”, menunjukkan inklusif, dan "we" menunjukkan keterbukaan.

Para penganut agama memberikan tanggapan atau respon terhadap doktrin agamanya. Dalam memberikan respon ini, para penganut agama setidaknya memiliki tiga kecenderungan yang bisa teramati. Menurut Komarudin Hidayat, ketiga kecenderungan itu, yang menurutnya bukan sebagai suatu pemisahan, adalah kecenderungan "mistis" (solitary), "profetik-ideologis" (solidarity), dan "humanis-fungsional". 38

Respon keberagamaan mistis, antara lain, ditandai dengan penekanannya pada penghayatan individual terhadap kehadiran Tuhan. Dalam tradisi mistik, puncak kebahagiaan

\footnotetext{
${ }^{36}$ Moran, Introduction To Phenomenology, 19.

${ }^{37}$ Flood, Beyond Phenomenology: Rethinking The Study of Religion, 67.

${ }^{38}$ Mark. C. Taylor, Critical Term of Religious Study (Chicago: Chicago universiy Press, 2010), 45.
} 
hidup adalah apabila seseorang telah berhasil menghilangkan segala kotoran hati, pikiran, dan perilaku sehingga antara dia dan Tuhan terjalin hubungan yang intim yang dijalin dengan cinta kasih.

Kecenderungan profetis ideologis ditandai antara lain dengan penekanannya pada misi sosial keagamaan dengan menggalang solidaritas dan kekuatan. Oleh karenanya, kegiatan penyebaran agama dengan tujuan menambah pengikut dinilai memiliki keutamaan teologis dan memperkuat kekuatan ideologis.

Yang ketiga, humanis fungsional, adalah kecenderungan beragama dengan titik tekan pada penghayatan nilai-nilai kemanusiaan yang dianjurkan oleh agama. Pada tipe ini, apa yang disebut kebijakan hidup beragama adalah bila seseorang telah beriman pada Tuhan dan lalu berbuat baik terhadap sesamanya. Sikap toleran dan eklektisisme pemikiran beragama merupakan salah satu ciri tipe ini.

Kecenderungan keberagamaan di atas hanyalah merupakan respon aksentuasi dan tidak identik dengan totalitas doktrin agama itu sendiri. Partisipasi dan pelaksanaan seseorang atas agama biasanya bersifat parsial, dibatasi oleh kemampuan, pilihan, serta kuat lemahnya komitmen iman seseorang. Namun demikian, dalam konteks hidup bermasyarakat dan bernegara, tipologi keberagamaan ketiga, yang menekankan orientasi kemanusiaan, perlu mendapat apresiasi dan penekanan. Hikmah hidup keberagamaan haruslah bermuara pada komitmen untuk menjunjung tinggi nilai-nilai kemanusiaan tanpa harus dihambat oleh sentimen kelompok keagamaan. ${ }^{39}$

\section{Epoché Teologis Sebagai Paradigma Pembangun Toleransi Beragama}

Epoché pada mulanya digunakan oleh aliran Pyrrhonisme, yakni aliran filsafat Yunani sekitar abad 272 SM, untuk mengungkapkan keraguan dalam ilmu pengetahuan, sehingga pendiri aliran filsafat tersebut, Pyrrhon, dianggap sebagai pendiri skeptisisme kuno Yunani. ${ }^{40}$

\footnotetext{
${ }^{39}$ Moran, Introduction To Phenomenology, 34.

${ }^{40}$ Moran, Introduction To Phenomenology, 36.
}

Pyrrhon juga dikenal sebagai pria bijak yang selalu berusaha menghindari perselisihan dalam ilmu pengetahuan tertentu dengan cara menangguhkan penilaian (praktek epoché) untuk diteliti terlebih dahulu. Pyrrhonisme sangat memengaruhi pemikiran para filsuf Eropa abad ke-17, terbukti dengan adanya istilah ini dalam tulisan-tulisan Kant pada tahun 1765, yang kemudian dipopulerkan filsuf Jerman Edmund Husserl dalam metode penelitian atas fenomena keagamaan sebagai respon terhadap penilaian-penilaian subjektif umat sekaligus kritik sistematis terhadap modernisme. ${ }^{41}$

Epoché digagas pertama kali dalam kajian fenomenologi agama oleh Husserl pada abad ke-19, di antara karyanya adalah "Phenomenology and the Foundations of the Sciences", "Logische Untersuchungen (Logical Investigations) (1901, 1913) dan "Meditations Cartésiennes (Cartesian Meditations)" (1931). ${ }^{42}$

Menurut Husserl, fenomenologi merupakan sebuah studi terhadap struktur kesadaran yang memungkinkan kesadaran tersebut mengacu kepada objek-objek di luar dirinya. Namun, semua itu tetap membutuhkan refleksi dari peneliti mengenai fenomena tersebut dengan mengenyampingkan segalanya. Husserl menyebut tipe refleksi ini dengan "reduksi fenomenologis", ia mencoba menghapus konsep dan konstruk pandangan seseorang dalam penelitiannya. ${ }^{43}$

Epoché menjadi ciri khas dalam fenomenologi Husserl, terutama dalam kecermatannya memperlihatkan dua hal penting. Pertama, kecermatan dalam menunjukkan akar permasalahan mendasar yang ada pada zaman modern, yaitu kesalahpahaman dalam memahami sifat dasar dunia dan sifat dasar manusia. Kedua, kecermatan dalam

\footnotetext{
${ }^{41}$ Moran, Introduction To Phenomenology, 36;Eliade, The Sacred and The Profan, 90.

${ }^{42}$ Moran, Introduction To Phenomenology; Eliade, The Sacred and The Profan;Schuon, The Transcendent Unity of Religions, 89.

${ }^{43}$ Proctor, Science, Religion and the Human Experience, 89.
} 
menunjukkan jalan keluar dari permasalahan modern tersebut, yaitu melalui sikap fenomenologis, khususnya epoché. ${ }^{44}$

Dalam karyanya, "Logische Untersuchungen" (Penyelidikan-penyelidikan Logika), dan "Philsophie als Strenge Wissenschaft", (Filsafat sebagai Ilmu yang Kuat), Husserl memperlihatkan bahwa filsafat modern terjebak ke dalam masalah perbedaan kategori yang salah antara subjek dan objek. Menurutnya, seluruh gerak pemikiran modern sejak Descartes, Hegel, dan John Stuart Mill hanya merupakan gerak psikologis yang bersifat subjektif terhadap seluruh realitas, kemudian mendudukkan manusia sebagai pusat seluruh pengetahuan.

Pandangan Husserl ini menjadi dasar baginya untuk menyebut filsafat modern sebagai psikologisme. Sedangkan psikologisme menjadikan manusia yang sadar itu sebagai awal dari segala sesuatu, dan kemudian seluruh realitas itu akhirnya akan kembali kepada kesadaran manusia sendiri. Inilah semangat optimisme modern yang pada awalnya bertujuan menegakkan kedudukan manusia sebagai manusia seutuhnya, namun terjebak ke dalam pemutlakkan atas manusia dan rasionya. ${ }^{45}$

Epoché memiliki sifat netral dalam penelitian keagamaan. Ia merupakan sikap yang coba menghindar dari penilaian yang diprakonsepsikan sebelumnya oleh seorang pemeluk agama yang meneliti fenomena keagamaan. Jadi, melalui epoché seorang fenomenolog dituntut untuk mendeskripsikan dan menjelaskan secara empiris suatu fenomena keagamaan, tanpa sudut pandang subjektif dirinya sebagai pemeluk agama. Epoché berada pada wilayah filsafat sekaligus teologi, namun adalah fakta bahwa manusia religius tepat saja dapat memengaruhi tindakantindakan dan tingkah-lakunya, sehingga ketika ungkapan keagamaan tersebut muncul darinya maka pengaruh tersebut akan terbawa ke dalam wilayah faktual. Artinya, seorang

\footnotetext{
${ }^{44}$ Proctor, Science, Religion and the Human Experience, 45.

${ }^{45}$ Proctor, Science, Religion and the Human Experience, 88.
}

fenomenolog tetap perlu mempertanyakan hakikat sebenarnya sebuah fenomena keagamaan melalui prinsip epoché tanpa harus terlibat untuk merumuskan baik-buruknya religiusitas atau moralitas suatu kasus. ${ }^{46}$

Epoché sangatlah fundamental dalam studi agama-agama. Ia merupakan kunci untuk menghilangkan sikap tidak simpatik, marah dan benci atau pendekatan yang penuh kepentingan (intertested approaches), dan fenomenologi telah membuka pintu penetrasi dari pengalaman keberagamaan baik dalam skala yang lebih luas atau yang lebih baik.

Bila semua umat beragama yang hidup dalam masyarakat multikultural mampu membuka sikap epoché, mereka bisa merasakan penderitan, suka duka atau bahkan kesenangan dengan umat berbeda agama. Sikap epoché dalam fenomenologi ini adalah sikap menunda, menahan diri bila seorang beragama bertemu dengan ajaran agama yang berbeda dengan ajaran agama yang dipeluknya. Keberagamaan dengan berpijak pada sikap epoché akan bisa menghargai umat berbeda agama dengan kesadaran sendiri dan bukan atas keterpaksaan atau ancaman.

\section{SIMPULAN}

Toleransi beragama tidak berarti bahwa seseorang yang telah mempunyai keyakinan kemudian berpindah atau merubah keyakinannya untuk mengikuti dan berbaur dengan keyakinan atau peribadatan agama-agama lainnya (sinkretisme); tidak pula dimaksudkan untuk mengakui kebenaran semua agama/ kepercayaan; melainkan bahwa ia tetap pada suatu keyakinan yang diyakini kebenarannya, serta memandang benar keyakinan orang lain, sehingga dalam dirinya terdapat kebenaran yang diyakininya sendiri menurut suara hatinya sendiri yang tidak diperoleh atas dasar paksaan orang lain atau diperoleh dari pemberian orang lain.

Masyarakat multikultural terpola oleh keragaman budaya termasuk keragaman

\footnotetext{
46

$$
\text { Wikipedia, }
$$$$
\text { "Epoché," }
$$

t.t., https://id.wikipedia.org/wiki/Epoch\%C3\%A9, diakses 02 April 2016.
} 
agama. Di dalam perjalanannya, agama-agama yang muncul dalam masyarakat multikultural kemudian dipahami oleh umatnya. Di antara mereka, ada yang memahaminya secara rasional an sich dan ada pula yang memahaminya secara irrasional atau mistis. Dampak heterogenitas agama ini bisa menmunculkan konflik di antara umat berbeda agama. Toleransi sangat dibutuhkan untuk menciptakn keseimbangan dan kohesi sosial dalam masyarakat multikutral. Untuk menciptakan sikap toleransi beragama yang proposional dalam masyarakat multikultural perlu menumbuhkan sikap epoché dalam berteologi. Sikap epoché ini mutlak diperlukan tanpa kompromi agar mereka bisa menjalankan toleransi beragama dengan baik. Jika sikap epoché ini tidak dimiliki, maka toleransi terhadap agama orang lain hanya akan sebatas basa-basi atau, sekalipun toleransi beragama bisa dilakukan, kecenderungan menyampur seluruh ajaran beragama atau menafikan ajaran agama dan digantikan dengan kepentingan nilai-nilai kemanusiaan yang bersifat umum dan sekuler akan muncul.

\section{DAFTAR PUSTAKA}

AS, Hornby. Oxford Advanced Learner'sDictionary. Oxford: University Printing House, 1995.

Cassanova, J. Public Religions In The Modern World. Chicago: Chicago University Press, 2008.

Eliade, Mircea. The Sacred and The Profan. New York, 1959.

Elmen, Paul. The Restoration of Meaning to Contemporary Life. New York: Garden City, 2012.

Flood, Gavin. Beyond Phenomenology: Rethinking The Study of Religion. London: Bloomsbury Academic, 2013.

Hidayat, Komaruddin. Menafsirkan Kehendak Tuhan. Bandung: Mizan, 2003.

Kinloch, Graham C. Sociological Theory: Development and Major Paradigm. Bandung: Pustaka Setia, 2005.

Lindbeck, Gerge A. The Natural Of Doctrne: Religion and Theology in a Post Liberal Age. Philadelphia: The Westminster Press,
1985.

Marty, Martin E. When Faiths Collide. New York: Blackwell Publishiers, 2004.

Moran, Dormort. Introduction To Phenomenology. New York, 2012.

Niebuhr, Reinhold. The Tolerance and Intolerance In Early Judiasm and Christianity. cambridge: Cambridge Universdity Press, 1998.

Parekh, Bikhu. Rethinking Multiculturalism;Cultural Diversity andPolitical Theory. New York: Palgrave Macmillan, 2005.

Proctor, James. D. Science, Religion and the Human Experience. New York: Oxford University Press, 2005.

Schoun, Fithjof. Islam and the Perennial Philosophy. Diterjemahkan oleh J.Peter Hobson. New York: World of Islam Festival Publishing Company, 1976.

Schuon, Frithjof. The Transcendent Unity of Religions. Cet. ke-2. Wheaton: Quest Books Theosophical Publishing House, 2005.

Shihab, Alwi. Islam Inklusif. Jakarta: Taraju Press, 2005.

Taylor, Mark. C. Critical Term of Religious Study. Chicago: Chicago universiy Press, 2010.

Wach, Joachim. The Comparative Study of Religion. New York: Colombia University Press, 1958.

Walzer, Michael. On Toleration Castle Lectures in Ethics, Politics, and Economics. New York: Yale University Press, 1997.

\section{Internet}

Wikipedia. "Epoché," t.t. https://id.wikipedia.org/wiki/Epoch\%C3\%A9. Diakes 02 April 2016. 